\title{
EXAMPLES OF GOOD PRACTICE IN SUSTAINABLE TOURISM DEVELOPMENT
}

\author{
Jelena Stajčić ${ }^{1 *}$, \\ Olgica Živković \\ 1Dnata d.0.0., \\ Belgrade, Serbia \\ ${ }^{2}$ Licenced tour guide
}

Correspondence: Jelena Stajčić

e-mail:

jelenastajcic011@gmail.com

\begin{abstract}
:
Given the progressive growth in the number of tourists in the last few decades, it has begun to think in the direction of preserving tourist destinations for future generations. There was an expression - sustainable tourism, a new form of smart destination development. This concept implies the preservation of the environment and the difficulty of neutralizing one of the most popular aspects of tourist movements, and that is mass. The initial idea was to show through the work that in Balkan region there are people from the tourism sector who are thinking about the so-called green tourism and how to fit it into the current world framework or sustainable development. Following the selected topic, through positive examples from practice, a presentation of different types of accommodation capacities is given, with a large price range and a diverse offer, with a common label, and that is «eco». At the end of the study the conclusion is imposed that it is possible to fit into nature and not disturb the existing, local socio-cultural developments while achieving efficiency benefits for all participants.
\end{abstract}

Keywords:

glamping, eco-hostel, slow hotel concept, eco villages, sustainability.

\section{INTRODUCTION}

The COVID-19 virus pandemic has led to a crisis of global proportions, changing the existing socio-economic structures in each affected country. A state of emergency or more restrictive measures of the movement has been introduced in many countries, which has led people to think more about the importance of preserving the natural environment because escaping into nature has become a kind of spiritual, physical, and psychological elixir in these times. Therefore, the current situation was the starting point for choosing a given topic. In the continuation of the work, new concepts of sustainable tourism in different accommodation capacities will be presented.

Slow living is a new philosophy of life that can also be applied in the hotel industry, which is to achieve harmony during your stay at the hotel and slow down the pace. A representative example in our country is Pegaz Holiday Resort in Vrnjačka Banja. 
On the other hand, as a more affordable counterpart, there is the first green hostel, Eco Hostel Republik in Užice, which is constructed to be energy independent, and this is achieved by placing solar panels on the roof. At the same time, the mentioned hostel enables each of its guests to be ecologically aware and responsible while staying in their space. As a gradual transition from accommodation in cities to natural oases deep in the forest are villages that fit into the green frame, and this paper will focus on the Wind Rose, which is located on the southern slopes of Fruška gora. Finally, as a good example of sustainable tourism but without giving up luxury habits is glamorous camping or glamping. Slovenia is a leader in this type of tourism, while the idea is still in its infancy in Serbia, and two more modest glamping places with potential will be presented, Bezdan and Jandala.

\section{SLOW LIVING CONCEPT}

The one of the most rapidly growing sectors of modern tourism is travel for health. Nowadays people don't need to be sick in order to opt for health and wellness tourism as their motive is improving and preventing overall health. Many visitors of modern health and wellness centres are unaware that the origin goes back to distant prehistory as it was believed that bath in the water results in physical and spiritual purification. From the end of the $18^{\text {th }}$ century until today, Roman baths were the basis of construction now already popular wellness centres that in functional and architectural terms represent a natural and material resource for the modern development of wellness and health tourism in the world. The practice of bathing came to European civilization from Greece, so Greeks established the foundations for modern spa procedures as they were the first to use standing bathtubs and washbasins for personal hygiene. In contemporary literature there are historical records for the origin of the term spa, from the Latin word "spargere" (scatter, sprinkle) or "Sanitas Per Aquam" (lat. water to health) or from the Belgian city of Spa, where a thermal spring (Jovanović, 2015) was discovered in the $14^{\text {th }}$ century. In the last decade of the past century, already the middle-aged generation of "baby boomers" showed awareness of the importance of good health by founding a wellness movement and development of the fitness industry.

Being healthy and feeling good - requires time, money and effort, which many people nowadays cannot afford. It is also important for each individual to recognize which aspect of his health requires attention in a certain period of life. There are times when more attention needs to be paid to physical health (during illness and recovery), but sometimes mental health is a priority (exposure to personal or occupational stress). The goal is to preserve health for as long as possible and improve health condition, where wellness contributes to the life quality of the individual by harmonization of its mental, emotional, physical and spiritual values. Wellness concept (Rabotić, 2013) is actually about integration of different components from the impact on improving quality of life, such as movement, physical exercise, balanced diet, relaxation and reduction of stress, but also feeling pleasure (holistic approach to health).

Slow living can be described as life philosophy, a state of consciousness and being, a meditative perspective, and methodical approach to daily life. It means connection with yourself, ones around you, and the world. Slow presents the opposite of the negative consequences "fast" has had for the health of people, societies and environment ". The Slow Living Vision is an Earth where humanity, celebrating and respecting the deep connection of all people, places and living beings, returns to you coexistence of mutually supportive communities, bioregions and economic systems - and where we, combining the wisdom of the past with a vision for the future, are ensuring the fulfilled and balanced life for all generations to come.

\section{Pegaz holiday resort in Vrnjačka Banja}

Pegaz Holiday Resort opens the possibility of a different reality in which presence now and here becomes a source of personal and social change which actually is the essence of existence. However, in order to master change, we need to master slowing down and thinking first. To slow down means to cultivate the awareness of the present moment, to make a conscious choice that never exhausts itself. To live slowly means to accept the principles that are naturally given to us: interdependence, uniqueness, simplicity, organization. 
By choosing a slow life, we accept interdependence with the environment in which we exist. To slow down means to free every day from unnaturally imposed restrictions and demands of the culture of modern living and working. Slow living mode is a kind of deliberate and thoughtful everyday life, an opportunity to choose what is really important. These are all those activities that make everyday life pleasurable and give it meaning through the conscious use of time.

Hotel offer consists of 120 suites, richly equipped slow wellness spa, cosy restaurant and bar Adut, and many other facilities which present a unique experience of slowing down. Pegaz Holiday Resort is a 4-star apart hotel, organized in three parts which covers over 10,000 square meters where guests can use numerous slow living facilities. In the Pegasus Slow Wellness Centre one can chose among some of the therapeutic and cosmetic treatments, as it consists of: salt room, sauna amphitheatre, infra sauna, bio sauna, Finnish sauna, experience showers, pool, Jacuzzi, relax room, massage room, steam bath, gym (Hotel Pegaz Holiday Resort, 2020).

After one Slow weekend stay at Pegaz Holiday Resort, person will feel the difference between work that consumes himself and work that fulfils him.

Slow workshop is the next step in the concept of team building as it is the program to slow down and restore the energy of tired teams. Team slowing down and relaxation is their flagship corporate program. In cooperation with company HR manager, Pegaz Holiday Resort will design a program for the team that will renew and refresh team's game.

Pegaz Holiday Resort offers the opportunity to have time. Busyness is not our business is an education program in small groups for everyone who wants to learn to have time. Whether you come from the culture of the business world or feel the pressure of not having time, Busyness is not our business is the appropriate program for you.

Warm colours and natural materials make every stay in the Adut restaurant a pleasant experience offering a completely new experience of enjoying well-known Serbian delicacies and desserts. Dishes are prepared from always fresh ingredients. Indulge in the magical experience of the richness of local flavours stored in a new way.

Within the Pegaz Holiday Resort complex, there is also the Dr. Gifing Centre for Preventive Medicine and Chrono Nutrition. Dr. Gifing's office provides users with all diagnostic procedures and preventive treatments developed by Dr. Ana Gifing:

-An individual approach prevents the development of the disease and helps in the early detection and treatment of existing metabolic disorders.

-Determination of individual tolerance and intolerance to certain foods and other allergens and food ingredients with a bioresonance device. This defines the foods that the patient should consume, i.e. which should be avoided in the daily diet.

-Counselling related to physical activity - type of physical activity, duration and weekly frequency of the same.

-Detoxification with the recommended supplementation (dietary supplements based on vitamins / minerals...)

\section{Chrono camp}

The cooperation of the experts - Dr. Gifing practice and Pegaz Holiday Resort in Vrnjačka Banja, resulted in the creation of a great idea and implementation of programs designed to regulate weight, restore fitness and provide guidance for those who want to live healthy. A specially designed program lasting 2 days is a safe and effective way to regulate body weight, provide desirable effects on health, but it is also only the first step in complete and permanent weight control and improvement of general health.

The Camp program is intended for everyone who wants something more than their vacation and those for whom health is in the first place in life. It includes workshops and lectures on chrono-nutrition, organized walks in nature, under the supervision of proven experts and nutritionists. 


\section{ENVIRONMENTALLY SUSTAINABLE BUSINESS IN HOTEL INDUSTRY}

It can be said that the development of eco-hotels and "green" hotels is a modern ecological trend tourism. Hotels have been intensively introducing "green" practices since the last decade of $20^{\text {th }}$ century, primarily due to the influence and pressure of the public to achieve consumer satisfaction, as economic impacts that are most related to operating costs, i.e. their reduction (Tzschentke et al., 2008). Environmentally sustainable business today is the most important element of corporate social hotel business responsibilities. To gain environmentally sustainable hotel business and social responsibility it is necessary to achieve synergy on the basis of consumer satisfaction, protection of natural resources, culture, economic and general well-being (Cooper, 2012). The first "green" hotel, 100\% eco-friendly, was opened by the Intercontinental Hotel Group-IHG (Fukey et al., 2014).

\section{Green key certificate}

Eco certificates and labels represent an important aspect for the ecological business of a hotel because they promote environmental sustainability and document the commitment of hotels in the implementation of measures and activities for protection and preservation of the environment.

For now, there is one eco-label in Serbia, and that is the Green Key, an award which can be considered as excellency standard in the sustainable tourism which gives Foundation for Environmental Education (2019). Since 1994 and the launch in Denmark by HORESTA (Association of the Hotel, Restaurant and Tourism in Denmark), it has officially aimed to raise awareness of certain future changes in tourism and hospitality generally and increase the use of environmental and sustainable methods.

A green key means that the hotel meets an appropriate set of environmental standards. The main goal of this certificate is to encourage social responsibility of the hotel through educational, joint and promotional efforts. This certificate developed criteria for obtaining a certificate for six categories of green keys (hotels and hostels, holiday parks and camps, conference centres, small accommodation facilities, attractions, restaurants), which include a list of 13 criteria based on activities covering those areas such as Corporate Social Responsibility, environmental facility maintenance, environmentally sustainable facility operations, equipping and maintaining accommodation units, waste management, water and energy facilities management, food and drinks preparation, employee education (Stanišić et al., 2019).

The basis of this certificate is the assignment of keys (from 1 - the lowest rating, to 5 - the highest rating) based on the hotel's compliance with the program of this label. The estimate is based on five main operational areas of the hotel business, including: corporate environmental management, cleaning and maintenance, engineering, conference and meeting facilities, food and beverage operations. In addition, the program covers nine areas related to sustainability in resource management: energy and water conservation, indoor air quality assessment, hazardous and solid waste management, infrastructure construction, land use and environmental management, community expansions.

So far, more than 3,200 facilities in 65 countries have received the Green Key (Foundation for Environmental Education, 2019). To obtain this eco-label hotels should confirm the fulfilment of all criteria related to education, employees, attitude towards environment, systematic application of measures and activities for protection and preservation of the environment and reducing resource consumption. This certificate was awarded in 2015 to the Radisson Blu Old Mill Hotel in Belgrade, which today operates under the name Radisson Collection Old Mill, and then in 2016 the Holiday Hotel In in Belgrade. In 2019 Hilton Belgrade received the Green Key eco certificate. From 2019 The Hotel Zlatibor Mona is part of the Green Key awarded establishments. It is the only one which received certificate outside of Belgrade. Since the renovation of the hotel in 2007 they never stopped acting to create an environmentally-friendly business. From the slow food concept of its restaurant to the use of environmentally friendly practices regarding water and energy, the Hotel Zlatibor Mona knows how to care of its guests while preserving the environment. Indeed, it contributes to the local communities' development by the employment of locals and the offering of scholarship programs for students, providing the latter with a job after graduation (Foundation for Environmental Education, 2019). 


\section{Eco hostel Republik}

Since the beginning in 2012 it has been dedicated to the idea of being environmentally friendly as a themed hostel conceived on the idea of preserving and protecting the environment and saving energy. The furniture and interior are made entirely from euro pallets designed for firewood. Cabinets, nightstands and other decorative elements that belonged to the Yugoslav army skilfully changed their purpose. Solar panels are installed on the roof as boilers which use sun energy. On the other side, hostel is reducing energy consumption by using energy-saving light bulbs. However, to reduce water consumption special showerheads are used. Their future plans are to install LED lighting from solar energy on the rooftop and to install battery-saving devices that regulate the time spent in the showers and to buy dish washers to save water consumption. In order to reduce $\mathrm{CO} 2$ emissions, the staff helps guests to find green modes of transport, such as walking, cycling and using local trains and buses. Fig. 1 shows example how toilets in hostel are made from natural materials trying to reduce energy consumption (Next Vision, 2018).

Figure 1. Toilets in Eco hostel Republik

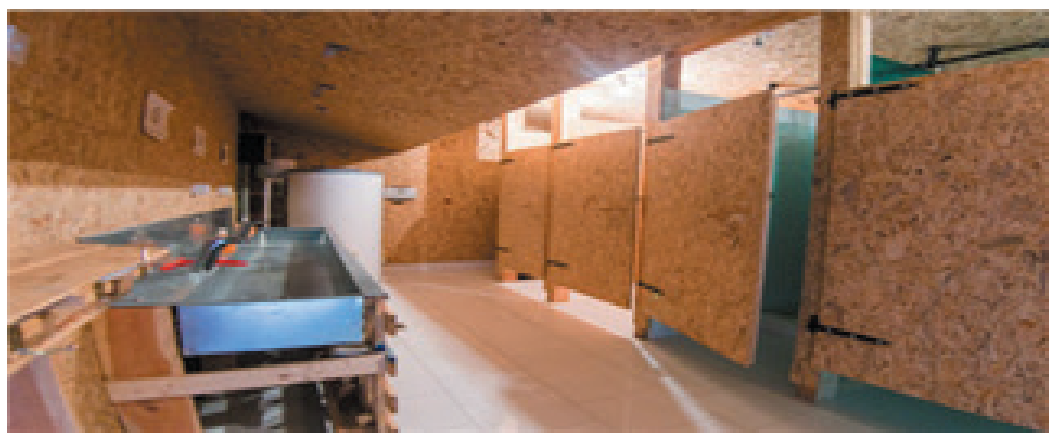

Source: https://www.republik.rs/green-idea/,

\section{ECO VILLAGE}

It seems that in rural areas, people who work with travel agencies or are registered on various web portals such as Airbnb or Booking.com, offering potential guests their accommodation, local food, various forms of recreation, and sightseeing first catch up with new trends and easily fit into the concept of sustainable tourism. In the countryside, people have always lived in harmony with by nature, those engaged in agriculture, fruit growing, or viticulture are accustomed to following the seasons, listening to nature to get the most out of the land, but trying not to disturb it to preserve it for their descendants. According to Rabotić (2013), rural tourism is the most complex segment of modern tourist trends, which in a narrower sense includes visits to villages and agricultural farms. It appeared in Europe only at the end of the $18^{\text {th }}$ century, when individuals inspired by the spirit of romanticism set out in search of idyllic villages as a potential refuge (Rabotić, 2013). It can be said that various forms of selective tourism such as agro tourism, gastro tourism, wine tourism, hiking, cycling, ecotourism that take place in a natural environment away from the urban area intertwine and arise from rural tourism. And, all the listed forms of tourism are covered by sustainable tourism, one of the important postulates of which is the care for natural resources, whether they are providers of tourist services or users of the same. Following the development and reshaping of rural tourism in Serbia, more and more purpose-built or existing ones are being turned into eco-villages. It is a form of a settlement whose inhabitants live in harmony with nature and strive to achieve their basic goal, which is the self-sustainability of the community, environmental protection, and the improvement of living standards (Pilipović et al., 2015).

If we look at the legal framework, the Law on Hospitality (Paragraf Lex d.o.o., 2020), in article 2, paragraph 12 defines a rural tourist household as a facility or group of facilities that provide accommodation, preparation, and serving of food, beverages, and drinks or only accommodation services, located in rural areas, rural environment with elements of local landmarks and heritage. 
Furthermore, article 18, paragraph 4 unequivocally states that catering facilities for accommodation of types of houses, apartments, rooms, and rural tourist households are categorized following the standards prescribed for certain types of those facilities. The next article 19 of the same law explains that the fulfilment of conditions on the spot is checked by the commission for categorization of catering facilities, which is elected by the competent minister. However, in practice this is not the case, in fact, the exact number of rural households that provide accommodation services on the territory of the Republic of Serbia is not known, because they are not registered or categorized. On the website of the Statistical Office of the Republic of Serbia, where all types of accommodation facilities are listed, there is an empty column for the total number of facilities in private accommodation, but the number of rooms is 10,047 and the total number of beds is 27,631 , it remains unclear how these data were obtained, only accommodation capacities of registered households or they have resorted to free assessment (Republički zavod za statistiku, 2020). Also, it must be noted that these statistics for private accommodation include both urban and rural areas, which further distances us from the real situation. Last December, the Serbian government and the Ministry of Trade, Tourism and Telecommunications (MTTT) presented the "e-Tourist" project (Creative Commons, 2020), a central information system (CIS) in the field of hospitality and tourism. It is a centralized electronic system that will contain all relevant data on accommodation providers, and will enable easier registration of domestic and foreign tourists, and thus facilitate the monitoring and collection of basic data on service providers and users, for further statistical processing. The project was done primarily to suppress the grey economy and regulate the area of renting accommodation facilities. Due to the current bad epidemiological situation in the country, the implementation deadline has been extended to October 1, 2020 and special emphasis has been placed on uncategorized rural household accommodation facilities to motivate them to apply to the Local Self-Government Units in whose territory they are located, for recording purposes. The fact is that unregistered households that rent accommodation operate outside the law, damaging the state budget by not paying the tourist local tax of 1 euro for foreign and domestic tourists, and do not pay income tax on the provision of catering services. For example. That money, if paid into the budget, could be redirected to solving infrastructural problems in rural areas.

Taking into account the above, when we talk about this year's increase in interest in the stay of domestic tourists in rural households, we can use only an obscure descriptive method based only on oral subjective assessments of household owners, so they state that "demand exceeded their expectations and requests for accommodation during the summer months are many times higher than for the same period last year, that the capacities were filled in June until September, etc. " On the other hand, if we compare the official statistical data for August last year, the increase in the number of arrivals and the number of overnight stays of domestic tourists in August of the current year in the entire territory of the Republic of Serbia is evident. In August 2019 the number of domestic tourist arrivals amounted to 210,509 , and this year it was increased by $25.3 \%$ and amounted to 263,719. In the same month, 812,505 overnight stays were realized in 2019, and this year in August 1,000,516 overnight stays were recorded, which is an increase of $23.1 \%$. (Republički zavod za statistiku, 2020).

Based on the presented data, we can partially report the correct conclusion that due to difficult conditions for traveling abroad, the vast majority of people turned to domestic tourism, supported by the number of inquiries for registered individual households through the Selo.rs internet portal. A good example of networking and unifying the offer is the site selo.rs, where you can find over 200 individual rural households from all parts of Serbia in one place. It is about the National Association "Rural Tourism of Serbia"(Selo.rs Seoski turizam Srbije, 2020), which was founded in 2002 by providers of rural tourism services, which are gathered in 9 associations. The site is user-friendly, where you can very easily choose the desired filters: destinations, lowest price, recommendation, last updated, guide me to get to the desired vacation home. Through the "shop" card on the site, you can order home-made products from hosts who are engaged in organic food cultivation.

\section{Eco villages - Koštunići (Kostunici) and Ruža vetrova (Wind rose)}

Two eco-villages with almost the same idea were taken with the intention, to serve as an example where one project was completed, brought to an end, and came to life, and the other is still in the process of realization. The first eco-village that was built in our country is Koštunići on the southern slope of the mountain Suvobor, near Valjevo. The village was created as part of the project "Integral Rural Development of the Suvobor region", 
which was implemented from 1997 to 2003 The ideological creator of the village is Mr. Jovan Čeković, who was born in this area and wanted to invest money in the preservation and development of the place where he came from.

Eco village has 76 beds, which are located in 4 apartments, 5 sculptures, and 7 balconies. Čardaci i vajati are wooden apartment-type houses depicting folk architecture in Serbia of the 18th and 19th centuries, only now modernized, each of the accommodation units of this type has underfloor heating, a luxury bathroom, and a TV. On the property in a separate part, there are 10 unusual round double rooms with bathrooms which are made in tubs. Fig. 2 shows a part of the barrels that were once used to store fruit and make brandy, and are now adapted for guests to stay. The settlement "Kaca" is located next to the lake, which was created by artificial means, by dividing the river Čemernica, so that during the summer season it is possible to swim and perform numerous activities on the water. Fig. 3 shows a part of an eco-village and a lake, on the shores of which volleyball and football fields were built. (Eko selo Koštunići, 2020).

Figure 2. Accommodation in old wooden barrels "Kaca"

Figure 3. Artificial lake in eco-village Kostunići

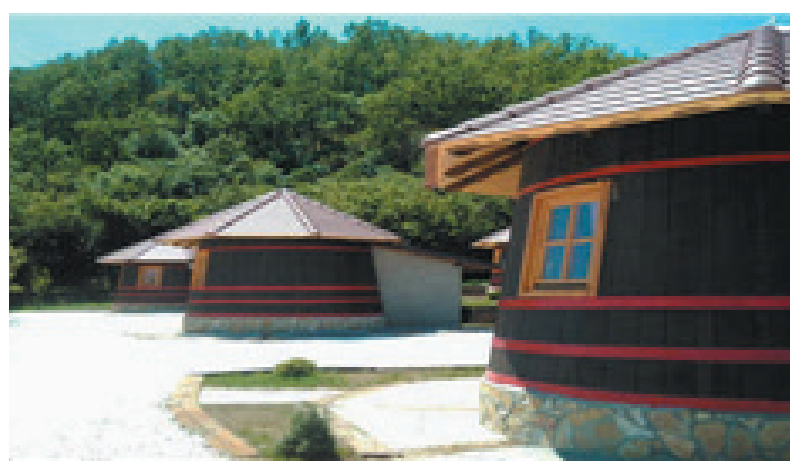

Source: ekoselo-kostunici.rs/ kostunici.rs/

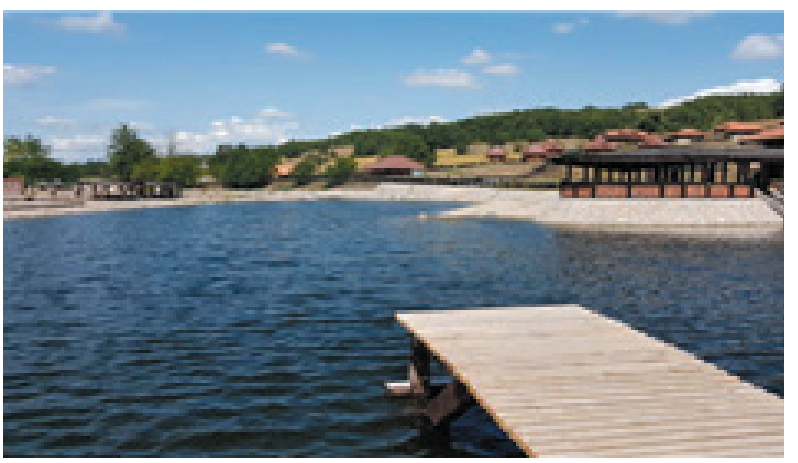

Source: ekoselo-kostunici.rs/ kostunici.rs/

A bio food factory was built in Koštunići, which is equipped with modern technology for processing fruits and vegetables, and the raw materials come from this area. This contributed to the involvement of the local community, motivated young people to stay in the countryside, which led to the revitalization of the place itself. The factory produces fruit brandies, sweets, honey, flour, natural fruit juices, ajvar (preserved peppersmade principally with red bell peppers, eggplant, garlic and chili pepper), and zimnica (a way to preserve fresh food like cabbage, tomatoes, cucumbers, or meat, or fruit in winter; one way is to put food in glass jars), (Recepti.com, 2019-2020). The value of the whole idea of preserving the village, improving the concept of eco, and developing the sustainability was awarded the "Tourist Flower" award for 2015 which is awarded by the Tourist Organization of Serbia in the category of catering facilities for accommodation.

About 1.5 million euros have been invested in the eco-village Ruža vetrova (Wind Rose) since 2015 and the complex behind which stands the company "Široki Horizont" is being built on the slopes of the mountain Fruška Gora near the monastery of Mala Remeta. Seven houses were built of natural materials, stone, and wood (Siberian cedar). All variations of the houses have a stone basement, living room, spacious porch (covered terrace), the upper part of which is built in the form of a $\log$ cabin where there are 2 or 3 rooms, depending on the area of the house. They are built on the principle of smart homes in which light sensors and air conditioners are installed, where the temperature is automatically adjusted, and electricity is used.

The plan is to build a restaurant with a summer garden, wellness, and spa centre with a swimming pool. It is interesting that by building a health trail that starts from the eco-village and leads through a picturesque forest, orchards, and vineyards all the way to the local winery, they combined the offer of these two different restaurants and provided a joint entry into the tourist market and achieved complementarity.

The eco-village Wind Rose is an interesting example because it can be observed in vivo how the project design is realized. When compared to the eco-village Koštunići, in addition to the initial similarities, one important difference is noticed when it comes to the ownership structure. 
Eco-village Koštunići is registered as a limited liability company, there is also a creator of the idea, owner, and they operate on the principle of renting accommodation. On the other hand, the eco-village Wind Rose operates on the principle of the condo concept, which implies ownership of houses and apartments, i.e., investors appear, they buy a house under construction and then use it during the year when it suits them, and for the rest of the year it is under professional management of the company. The condo concept of ownership and issuance is still new in our real estate market, so in addition to fitting into the concept of sustainable tourism, it is certainly a big step in the development of eco-villages in our area and it is following prudent and economical use of all available resources. Fig. 4 shows one smaller house of $110 \mathrm{~m}^{2}$ and larger of $209 \mathrm{~m}^{2}$ out of a total of seven built. (Ruža vetrova eko-selo, 2020).

Figure 4. Panoramic view of the eco-village Wind Rose

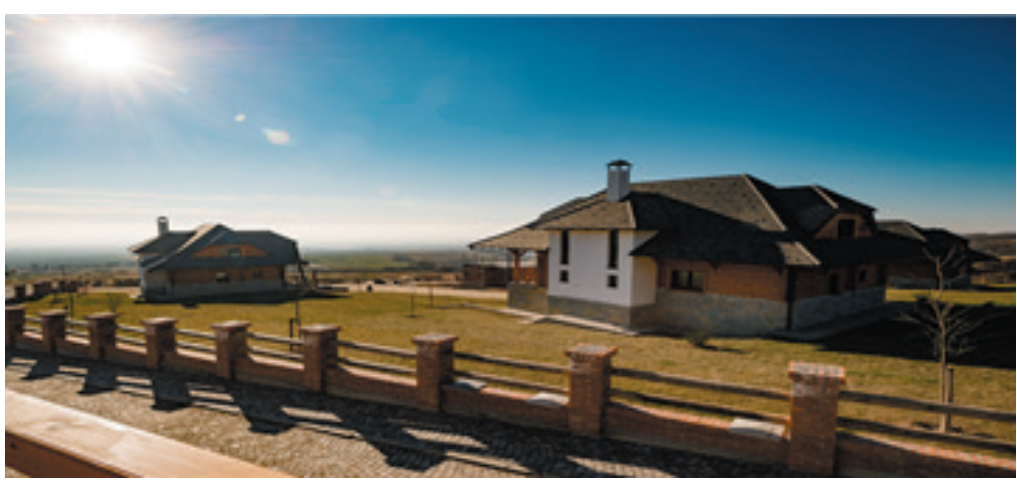

Source: https://www.slikavest.rs/ruza-vetrova-dom-u-prirodi-o-kakvom-ste-sanjali/

\section{GLAMPING}

The term glamping officially entered dictionaries some 15 years ago, it was created by combining two well-known words, glamor and camping. Strangely these two concepts that have no points of contact and that are related to different social strata have merged. However, tourism has found it necessary to connect them. Simply put, glamping is a luxury camping and perfectly suits high-paying people who care about comfort to which they are accustomed by staying in high-class hotels but want to escape away from the busy city into a natural oasis due to overloaded with daily obligations, fast business pace, and relax in the fresh air restoring psychophysical balance. Glamping in every sense represents exclusivity. On the one hand, tents are equipped with comfortable beds, bathrooms with whirlpool tubs, equipped kitchens, coffee machines, there is often a restaurant nearby, private service, that is the part of glamor. On the other hand, the location is specific, usually deep in the woods, by a river or lake, at the foot of a mountain, under a starry sky, and it is the location that is a direct link to classic camping. If we look at the roots of glamping, we come across examples from the past. A representative example comes from the historical past of France, on the Field of the Golden Canvas (today the city of Bellingham) in 1520, 2,800 luxury tents with canopies for two kings were set up, English Henry VIII and French Francis and their numerous entourage (Kosar, 2017).

In the last decade, Slovenia has been promoted on the world tourist scene as a green destination whose imperative is sustainable development. In 2016, Ljubljana was declared the green capital of Europe. So, it is not surprising that Slovenia is the absolute leader in the region for luxury camping. One of the most representative sites for searching glamping locations around the world is glamping.com, where Slovenia ranks high second in Europe.

Garden Village Bled is in the top 10 destinations for glampers according to National Geographic, they received the Trevellers' Choice award from Tripadvisor for the best comments from guests in continuity; for 2020 they offer several luxury accommodation facilities from 25 to $35 \mathrm{~m}^{2}$. Guests can stay in a glamorously equipped tent, a treehouse, a tent for two on both streams or an apartment that has heating, a kitchen with all appliances, and a private balcony. Everything is subordinated to relaxation; guests, if they want to be more active, can rent bicycles or scooters. The slogan of the resort is "Fill your lungs with fresh air". 
The enchanting landscape around the lake assures guests that sometimes it is enough to just sit by the lake and breathe to achieve inner peace. There is a possibility of gift cards for glamping, the lowest amount is 50 euros, and the highest is 1,000 euros gift certificate. (Garden Village Bled, 2020).

Serbia cannot be compared to Slovenia in terms of luxury camping, it can be said that this way of spending a vacation in the heart of nature in a more comfortable and far more expensive way has not been met with a good response in our country. However, the paper will present two places that fall under the category of glamping, but strictly speaking, they are not luxury accommodations and are more a kind of social glamping. They are taken as an example because they have the potential to develop in the direction of luxury accommodation in a natural environment.

Camp Bezdan is located on the shores of the Grand Bačka Canal, $20 \mathrm{~km}$ from Sombor. They offer classic tents that are equipped with 2 to 4 beds and the rental price ranges from 20-30 euros. The price itself speaks in favour of the fact that this is not the right concept of glamping, because the prices in neighbouring countries range from 110 euros and up, depending on the size of the tent and all the accompanying comforts. It has a fishing pier and the possibility of renting a canoe. The camp offers classic tents and camping places that are rented at a price of 7 euros. The good side is the location itself, which provides numerous opportunities for excursions, water sports, and getting to know the local customs and culture of Vojvodina. (Kamp Bezdan, 2020).

Jandala is located on a hill above the Danube in Krčedin, less than an hour's drive from Novi Sad and Belgrade. It is a more developed type of settlement but also does not fit into glamping standards; accommodation units are wooden houses and rooms and it offers modestly equipped tents, but does not have all the equipment that adorns glamping locations around the world. The capacity is 30 people and interestingly it is issued only twice a month for individual inquiries, on all other days it is for groups only. It is a great advantage that Jandala has a large hall of $140 \mathrm{~m} 2$ which is equipped with a special floor base suitable for exercises and dancing. During the summer, the charm of the estate is represented by wooden lookouts suitable for smaller meetings with an enchanting view of the Danube. (JandaLa imanj, 2019).

\section{STATISTICAL DATA}

The explanation of both tables is based on data from Statistical Office of the Republic of Serbia (2019-2020). In the Republic of Serbia in August 2020 compared to August 2019, the number of total tourist arrivals decreased by $34.3 \%$. In August 2019, a total of 448,310 tourists stayed in Serbia, and we can see from Table I that in the same month in 2020, only 294,334 tourists stayed. If we look at foreign tourists, in August 2020 there were only 30,615 of them, which is a decrease of as much as $87.1 \%$ compared to August 2019, when there were 237,801 of them in the country. The table shows in yellow the increase of domestic tourists by $25.3 \%$, which was recorded in August, when 263,719 domestic tourists stayed in Serbia, while in the same month last year, in 2019, there were 210,509 tourists.

Table I. Number of tourist arrivals in Serbia - comparison 2019/2020

\begin{tabular}{cccccccccccc}
\hline & \multicolumn{1}{c}{ Total arrivals in 2020. } & \multicolumn{3}{c}{ Domestic tourist arrivals (2020) } & \multicolumn{3}{c}{ Foreign tourist arrivals (2020) } \\
\hline August & I-VIII & $\begin{array}{c}\text { Percentage } \\
\text { change } \\
\text { rate for } \\
\text { August }\end{array}$ & $\begin{array}{c}\text { Percentage } \\
\text { change } \\
\text { rate } \\
\text { for I-VIII }\end{array}$ & August & $\%$ & I-VIII & $\%$ & August & $\%$ & I-VIII & $\%$ \\
\hline 294334 & 1269031 & $-34.3 \downarrow$ & $-49.1 \downarrow$ & 263719 & $25.3 \uparrow$ & 948470 & $-26 \downarrow$ & 30615 & $-87.1 \downarrow$ & 320561 & $-73.5 \downarrow$ \\
\hline
\end{tabular}

Source: Tables prepared by the authors according to available data from the Statistical Office of the Republic of Serbia (2020), 264ut10avg.xls (stat.gov.rs) 
The number of total overnight stays decreased by 17.1\% in August 2020, compared to August 2019. Regarding tourist overnight stays in Table II, the increase in the number of overnight stays of domestic tourists is also marked in yellow. In August 2019, domestic tourists realized 812,505 overnight stays, and in August 2020 domestic tourists made 1,000,516 overnight stays which is $23.1 \%$ more. Due to the well-known situation with the coronavirus, the number of overnight stays of foreign tourists has drastically decreased this year by as much as $83.7 \%$. This year, only 80,160 overnight stays were realized, and in August 2019, foreign tourists realized 490,339 overnight stays.

Table II. Number of overnight stays in Serbia - comparison 2019/2020

\begin{tabular}{|c|c|c|c|c|c|c|c|c|c|c|c|}
\hline \multicolumn{4}{|c|}{ Total arrivals in 2020.} & \multicolumn{4}{|c|}{ Domestic tourist arrivals (2020) } & \multicolumn{4}{|c|}{ Foreign tourist arrivals (2020) } \\
\hline August & I-VIII & $\begin{array}{l}\text { Percentage } \\
\text { change } \\
\text { rate for } \\
\text { August }\end{array}$ & $\begin{array}{c}\text { Percentage } \\
\text { change } \\
\text { rate } \\
\text { for I-VIII }\end{array}$ & August & $\%$ & I-VIII & $\%$ & August & $\%$ & I-VIII & $\%$ \\
\hline 1080676 & 4354506 & $-17.1 \downarrow$ & $-37.7 \downarrow$ & 1000516 & $23.1 \uparrow$ & 3478439 & $-20.1 \downarrow$ & 80160 & $-83.7 \downarrow$ & 876067 & $-66.8 \downarrow$ \\
\hline
\end{tabular}

Source: Tables prepared by the authors according to available data from the Statistical Office of the Republic of Serbia (2020), 264ut10avg.xls (stat.gov.rs)

- According to Slovenian data (connection) 2,069,194 million overnight stays were registered in July 2020 , including 1,398,871 million domestic and 670,323 thousand foreign.

- The number of domestic stays was increased by $154.5 \%$, and foreign stays decreased by $66.3 \%$, so the total number decreased by $18.5 \%$. Overnight stays of domestic tourists are stimulated with vouchers of 200 euros each for use in the accommodation capacities of Slovenia. (Makroekonomija, 2020).

\section{CONCLUSIONS AND DISCUSSION}

At the end of the study the conclusion is imposed that it is possible to fit into nature and not disturb the existing, local socio-cultural developments while achieving efficiency which benefits for all participants. The results of the research show that rural tourism was the most intensive in Serbia due to the existing pandemic, and in June almost all accommodation facilities in rural areas were reserved for the entire summer season, until mid of September. Burnout syndrome at work is no longer a synonym for managerial illness but affects all structures in a company from the management structure to the employees, so it is certain that slowing down and escaping to hotels that use Slow living will become a new trend in our country. This year's health crisis has affected all sections of the population, some are returning to family farms and starting businesses, deciding to enter entrepreneurial waters, opening restaurants, renting accommodation in rural houses, growing organic food. This March when epidemic started Alliance for Innovators and Researchers in Tourism and Hospitality (AIRTH) and Tourism 4.0 Partnership joined forces for sustainable and responsible tourism development in post COVID-19 world and initiated \#TourismFromZero. All this leads to the conclusion that in fact eco-tourism, perhaps even more than other forms of tourism, involves the local community, connects them with various state institutions directly responsible for environmental protection, and provides opportunities to work together on projects and apply for grants provided by numerous European funds and promotes the development of eco-tourism. 


\section{REFERENCES}

Ar@tur (2019). Tourism from Zero. Retrieved September 20, 2020, from Tourism from zero - Tourism 4.0 (tourism4-0.org).

Cooper, C. (2012). Essentials of Tourism. New York: Pearson Financial Times Prentice Hall.

Creative Commons (2020). E turista. Retrieved December 1, 2020, from Актуелно (eturista.gov.rs).

Eko selo Koštunići (2020). Sve o eko-selu. Retrieved September 20, 2020, from Еко село Коштунићи : Еко село Коштунићи (ekoselo-kostunici.rs).

Elegant Themes (2020). What is Slow Living. Retrieved September 15, 2020, from What Is Slow Living? - Slow Living Summit.

Foundation for Environmental Education (2019). Our Programme. Retrieved September 10, 2020, from Green Key - Green Key programme.

Fukey, N. L., Issac S. S. (2014). Connect among Green, Sustainability and Hotel Industry: A Prospective Simulation Study. International Journal of Economic and Management Engineerin.8 (1), 296-312. Retrieved September 16, 2020, from https://publications.waset.org/9997483/connect-among-green-sustainabilityand-hotel-industry-a-prospective-simulation-study. DOI: 10.5281.1090835.

Garden Village Bled (2020). About Garden Village. Retrieved September 20, 2020, from Garden Village Bled.

Hotel Pegaz Holiday Resort (2020). Slowliving. Retrieved September 15, 2020, from Slowliving - Pegaz Holiday Resort (hotelpegaz.com).

JandaLa imanje (2019). Glamping šatori. Retrieved September 20, 2020, from Glamping šatori - Jandala.

Jovanović, V. (2015). Tematski turizam (2. izmenjeno i dopunjeno izdanje). Beograd: Univerzitet Singidunum.

Kamp Bezdan (2020). O kampu. Retrieved September 20, 2020, from Kamp Bezdan - Vodeći glamping kamp u Srbiji.

Kosar, Lj. (2017). Glamping - Inovativni oblik turističkog smeštaja. HOTELlink. 29-30 (1), 17-27. Retrieved September 20, 2020, from https://ehl.vhs.edu.rs/poslednji-broj/. ISSN:1451-5113.

Kyle Kowalski (2018, June). Slow Living 101: What is Slow Living?. Retrieved September 15, 2020, from Slow Living 101: What is Slow Living? | Sloww.

Makroekonomija (2020). Slovenački patriotizam:povećan broj domaćih noćenja za 154,5\% u julu 2020. Retrieved September 20, 2020, from https://www.makroekonomija.org/slovenija/slovenacki-patriotizam-povecanbroj-domacih-nocenja-za-1545-u-julu-2020/.

Next Vision (2018). Green idea. Retrieved September 10, 2020, from Green Idea - Eco Hostel Republik.

Paragraf Lex d.o.o. (2019). Zakon o ugostiteljstvu. Retrieved Decembar 1, 2020, from https://www.paragraf.rs/ propisi/zakon-o-ugostiteljstvu.html.

Pilipović, T. D., Mišković, I., Subić, J., Jeločnik, M., Ilić, M., Milanković, D. (2015). Eko selo kao model ruralnog razvoja i ekonomskog osnaživanja srpskih sela. Vrmdža, Sokobanja: Centar za društveno odgovorno preduzetništvo - CDOP.

Rabotić, B. (2013). Selektivni oblici turizma (Drugo izdanje). Beograd: Visoka turistička škola strukovnih studija.

Recepti.com (2019-2020). Bakin ajvar sa crvenim i plavim paradajzom. Retrieved Decembar 1, 2020, from https://www.recepti.com/kuvar/zimnica/17795-binkin-ajvar-sa-crvenim-i-plavim-paradajzom.

Republički zavod za statistiku (2019). Turistički promet-avgust 2019. Retrieved September 20, 2020, from https:// publikacije.stat.gov.rs/G2019/Pdf/G20191261.pdf.

Republički zavod za statistiku (2020). Turistički promet-avgust 2020. Retrieved September 20, 2020, from 264ut10avg.xls (stat.gov.rs).

Ruža vetrova eko-selo (2020). O kućama. Retrieved September 20, 2020, from Kuće - Ruža Vetrova (ruzavetrova.rs).

Selo.rs Seoski turizam srbije (2020). Vodi me. Retrieved September 20, 2020, from Smeštaji U Srbiji - Zima 2020/2021 | Pogledajte Slike I Cene | Selo.rs.

Stanišić M., Radović N., \& Nikolić J. (2019). Review of sustainable business and profitability of eco-friendly hotels in Serbia. Finiz 2019-Digitization and Smart Financial Reporting, 06 December 2019 (pp. 15-19). Belgrade, Serbia: Singidunum University.

Tzschentke, N., Kirk, D., \& Lynch, P. A. (2008). Going green: Decisional factors in small hospitality operators. International Journal of Hospitality Management, 27 (1), 126-133. Retrieved September 16, 2020, from https:// www.sciencedirect.com/science/article/abs/pii/S0278431907000497. DOI:10.1016/j.ijhm.2007.07.010. 